\title{
A crusader screw press form from Western Galilee - The manot press
}

Rafael Frankel and Edna Stern

\section{(2) OpenEdition \\ 1 Journals}

Electronic version

URL: https://journals.openedition.org/tc/484

DOI: $10.4000 /$ tc. 484

ISSN: 1952-420X

Publisher

Éditions de l'EHESS

Printed version

Date of publication: 1 October 1996

ISSN: 0248-6016

Electronic reference

Rafael Frankel and Edna Stern, "A crusader screw press form from Western Galilee - The manot press", Techniques \& Culture [Online], 27 | 1996, Online since 28 October 2005, connection on 29 September 2022. URL: http://journals.openedition.org/tc/484 ; DOI: https://doi.org/10.4000/tc.484

This text was automatically generated on 29 September 2022.

All rights reserved 


\section{A crusader screw press form from Western Galilee - The manot press}

Rafael Frankel and Edna Stern 